\title{
WHERE THE SIDEWALK ENDS: Automobility and Shame in Tbilisi, Georgia
}

\author{
PERRY MAXFIELD WALDMAN SHEROUSE \\ (iD) http:/ / orcid.org/0000-0001-6567-3095
}

In July 2015, I met the urban planner Vladimir (Lado) Vardosanidze in front of the Tbilisi Concert Hall, a round, glass-plated building located at the convergence of a bewildering traffic pattern where two multilane one-way streets combine in a swirl of traffic to form a bidirectional road that becomes the main drag in Tbilisi's downtown. Lado, a spry seventy-year-old professor with specializations in urban planning, architecture, and culture, greeted me with a smile and told me that he had selected this location to meet because he wanted to point out some features of the urban landscape that were indicative of larger trends in the development of Georgia's capital city. This area, he told me, was nicknamed the Bermuda Triangle because of the erratic traffic patterns that render it particularly dangerous for pedestrians. As we walked toward his home office nearby, Lado drew my attention to a variety of sidewalk hazards: a set of plastic bollards that had been cut off at the base to allow cars to park on the sidewalk, loose and missing bricks in the pavement that made walking treacherous and wheelchair travel impossible, and a kiosk situated so close to the curb by a bus stop that it forced riders to wait on the street rather than the sidewalk, with the sharp edge of its exterior metal counter positioned at eye-level overhanging the ramp from sidewalk to street. ${ }^{1}$ Cars were parked on the sidewalks, and pedestrians dodged 
traffic to cross the busy street. The boundary between street and sidewalk was at risk of collapsing, and with it, the moral orders that the sidewalk symbolically supported.

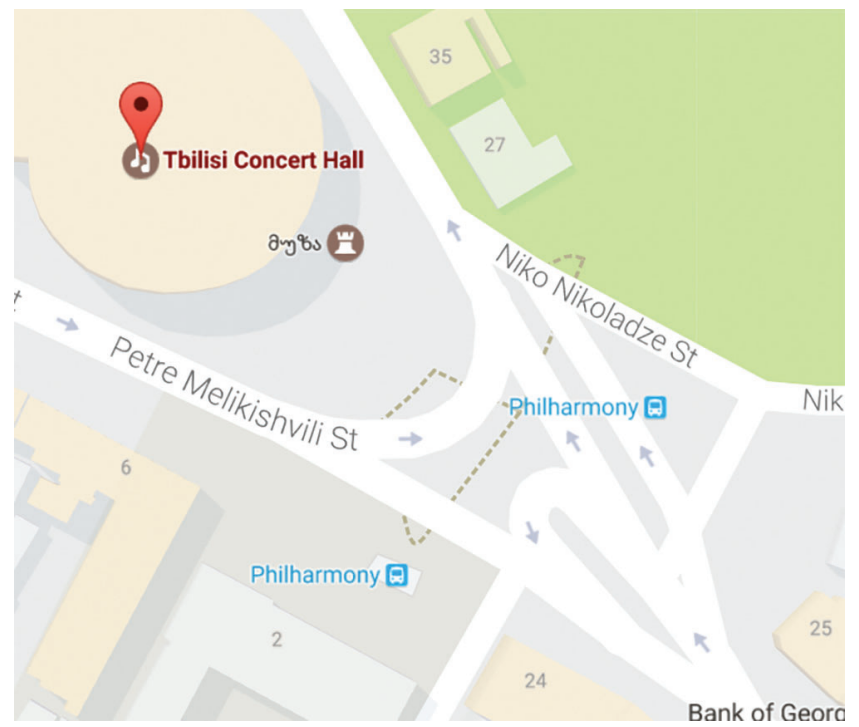

Figure 1. The "Bermuda Triangle" traffic pattern in front of the Tbilisi Concert Hall. The glitzy rotunda stands on a concrete expanse flanked by steps descending to the tunnels of an underpass, a series of underground crosswalks by which pedestrians traverse a city block in order to reach Vera Park, where there is a busy bus stop and taxi pickup point. Map data by Google.

Cars have steadily colonized the sidewalks in downtown neighborhoods in Tbilisi since I first visited in 2009. In recent years, the process has intensified. According to Lado, the municipal and cultural acceptance of behaviors such as driving or parking on sidewalks is one of several developments in Tbilisi urbanism since the 1990s that have set new unfortunate precedents. Once established as normative, certain modes of public comportment prove difficult to reverse. Lado contended that many decisions by the local government had ignored urban planning and environmental considerations in crafting Tbilisi's urban landscape, demonstrating the triumph of private over public interests (Vardosanidze 2003, 2009). After the political instability and economic hardship of the 1990s, the pattern of urban development since 2003 shifted toward the privatization of transportation and a rise in what some critics have termed "investor urbanism" (Van Assche and Salukvadze 2013, 94). Following the 2003 Rose Revolution, Mikheil Saakashvili and the United National Movement (UNM) ousted Eduard Shevardnadze and 
came to power, implementing changes to the built environment as a means to remake public perception. Transformations of public space, such as the construction of glass police stations meant to symbolize transparency, have provoked scholarly inquiries into the political and social significance of the broader project that is afoot in the architectural reshaping of Tbilisi urbanity (Frederiksen 2012; Curro 2015). ${ }^{2}$ Mundane elements of urban material culture, such as parking, also underwent renovation during the same period. This article focuses on the politics of parking as a way to understand contested visions of the public good taking place at the edges of official, large-scale urban development projects.

The sidewalk bisects public and private life, and as a consequence it has become an enduring trope in narratives about how modernity can be reconstituted. In Georgia, this reconstitution has involved literally standing on cemented layers of the Soviet past, while tempering the meaning of these layers with corporate interests, emerging environmental concerns, and visions of a European material and ideological future for the built environment. Disputes about parking engage fundamental questions about the forms that urban public spaces and transportation systems should take. The conflict between two dominant modes of urban order - vehicle-centered or pedestrian-centered - is a central object of concern for citizens, planners, and urban theorists alike (Jacobs 1961; Berman 1982; Holston 1999). Resolutions, compromises, and redescriptions of this fundamental conflict manifest different perspectives on the functions that sidewalks serve as elements of public space. Although the tension between pedestrianism and automobility has been present in urban modernism since the nineteenth century, in the twenty-first century this conflict has become more pressing as privatizationcentered urban growth and a dystopian present of automobility grind against desires for ecological sustainability and urban livability. As this conflict has become more acute around the world, the remaking of the city has received increasing attention: from the promotion of bike lanes, pedestrian zones, and green spaces, to a restructuring of public transportation.

Shame has entered into discourses of urbanism as an instrument of pedestrian activism. For example, members of the Young Greens (Green Party; akhalgazrda mts'vaneebi), launched a campaign against large vehicles called didi jipi = pat'ara ch'uch'u (large jeep = small penis), which targeted SUVs and other large vehicles as signs of conspicuous consumption. ${ }^{3}$

This shaming campaign connected masculine insecurity with social and environmental disregard. On June 30, 2015, I met with several members of the Young Greens to learn about their organization's vision and programs. Following 


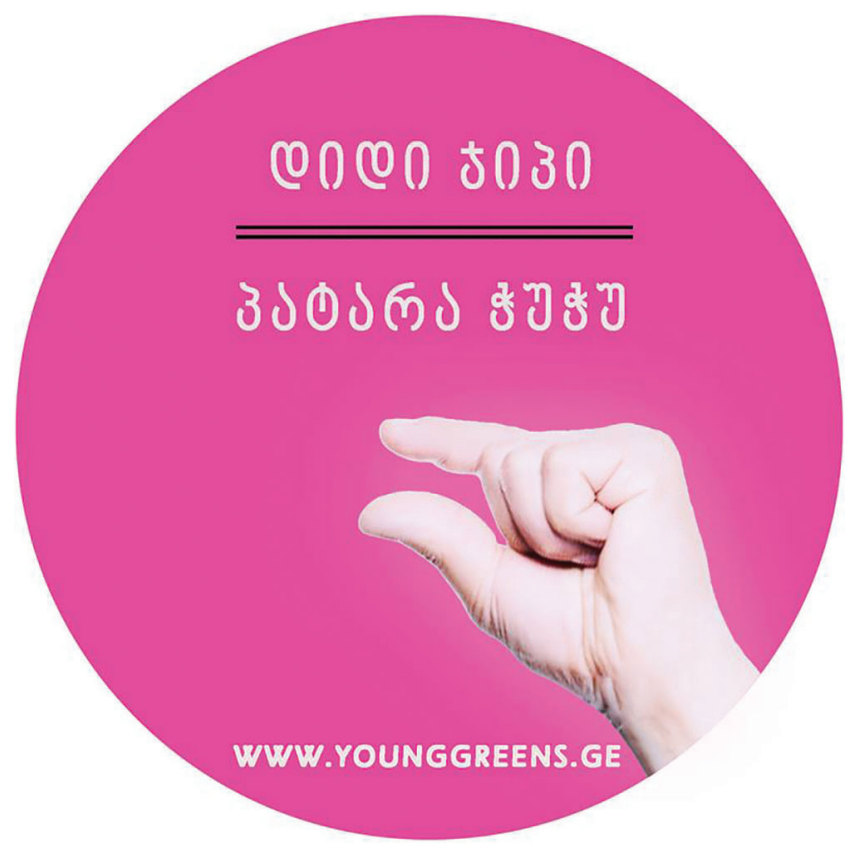

Figure 2. Image from the didi jipi = pat'ara $c h$ 'uch'u (large jeep = small penis) campaign . Image by the Georgian Young Greens.

the large jeep $=$ small penis campaign, they were working on a policy document focused on transportation in Tbilisi. They defined themselves as a leftist political and activist organization with a broad agenda of political change, in which ecological and transportation issues were just two dimensions. I inquired about why, in recent years, the number of organizations of young people in Tbilisi trying to change urban space had increased and become more visible. One of the members, Stela Namgaladze, offered multiple reasons, including an increase in old and cheap cars (that make it so you "can't move” on sidewalks), a lack of ecological regulations resulting in greater emissions, and a government under which "young people see that they can express themselves more freely." She added that "this kind of activism became cooler than it was five years ago . . . but only in terms of this ecological stuff and this urban stuff, not with worker rights or something." She added that for urban and ecological issues, they could mobilize thousands, whereas other campaigns, such as the May 1 International Workers' Day events, only attracted a hundred supporters. In reference to the large jeep $=$ small penis campaign, another member of the group emphasized that the proliferation of 
vehicles in urban space partly resulted from the social status that these vehicles conferred, an association that the campaign sought to challenge.

It is not surprising that affect plays a role in activism. What is distinctive, in this case, is how shame operates to inform, but not determine, the perspectives around which activists mobilize in Tbilisi. Shame draws together a series of asymmetric power relations without catalyzing a particular form of politics against them. As Silvan Tomkins $(1995,139)$ points out, shame-humiliation "does not renounce the object of identification permanently, whereas contempt-disgust does." Shame, as a dominant affect and discursive hinge in activist interventions, organizes a series of asymmetric power relations, including geopolitical (between Russia and Georgia), modal (between local car-driving elites and proponents of pedestrianism and public transportation), and aspirational (between an imagined European order and a lived urban experience characterized by dismal frictions). While shaming belongs to the domain of environmental activist tactics in many parts of the world, what is notable in this context is that the promotion of pedestrianism, as a seemingly neutral ideology about comportment in public space, is politically underspecified and can therefore be associated with either capitalist or socialist values.

This article draws on fifteen months of fieldwork conducted in Tbilisi in 2009, 2011-2012, and 2015. My perspective on Tbilisi urban life is informed by the traffic, parking, and pedestrian discomforts I witnessed there. The rapid growth of car ownership since the 1990s has exerted pressure on urban infrastructures, as the city was not planned with extensive automobility in mind. Old, cheaply purchased cars crowd the roads, producing environmental strain, road fatalities, noise, and an increasingly congested road and parking system. ${ }^{5}$ Cars comprise part of a larger infrastructure that the sociologist John Urry (2004) has termed "automobility," or what Catherine Lutz and Anne Lutz Fernandez (2010, xi) term the "car system" (see also Lutz 2014). ${ }^{6}$ Within the Tbilisi car system, I found that contestations over sidewalk space revealed a moral underpinning to the banality of parking. In the media, political discourse, or casual discussion among friends and acquaintances, conversations about sidewalks quickly turned to the moral qualities that the city has engendered in its citizens. What seemed like a chaotic collapse of sidewalk order gave rise to a host of responses about the primacy of certain material and social practices as pathways, literally and figuratively, to civilizational modernity (or what Saakashvili, in a speech in 2013, referred to as Georgia's "European destiny"). Like much of the public symbolic 
repertoire in Tbilisi, sidewalks function as a prism refracting the neoliberal cityscape through the mixed legacies of Soviet modernism.

In what follows I first describe some of the frictions in Tbilisi's car-andsidewalk system that have emerged from the juxtaposed logics and legacies of liberal and socialist urbanism. I then focus on two authorities that organize public parking in the contested zone of the sidewalk in Tbilisi: the corporate parking company CT Park and self-appointed parking attendants. The afterlife of socialist urbanism has resulted in a situation in which different institutions of parking order coexist, for the moment, under the pressures of an expanding car system. In the final section, I analyze how pedestrian activists in postsocialist space share forms of engagement by connecting the Georgian case with the contemporaneous Stopkham ("Stop a Douchebag”) campaign in Moscow, Russia. Activists attempt to redirect their frustration and sense of shame toward obnoxious drivers, transforming imagined global hierarchies into admonitions about failures of personal responsibility. The comparison between Russian and Georgian activists demonstrates an emerging sensibility of pedestrian rights across postsocialist spaces. Even as Georgian activists recognize a substrate of commonality with Russian activists, they are careful to disavow direct Russian influence on the strategies they adopt.

\section{SIDEWALKS IN SOCIALIST MODERNITY}

Sidewalks show the economic, political, and social stakes of the public good at a different scale than other transportation infrastructures, such as roads and highways. The adjacency of the sidewalk and the road has meant that the tropes each engages (such as freedom, connectivity, and movement) work in parallel. ${ }^{7}$ Social-scientific scholarship on the sidewalk has registered the power relations, ideological orientations, and imaginative and affective parallels among the various institutions and actors that exert influence over the contours of public space. Jane Jacobs $(1961,29)$ famously wrote that sidewalks, the "pedestrian parts" of the streets, "serve many purposes besides carrying pedestrians." Research on sidewalks has stressed their multiplicity of functions, particularly as domains of commerce, mobility, and sociality (Duneier 1999; Kim 2015; Goldstein 2016). Much of the literature on urban design celebrates the multifunctional, crowded sidewalk as a source of enjoyment and prosocial frisson, providing what William Whyte (2000, 242) termed "vital frictions." By contrast, I concentrate on the negative dimensions, or dismal friction, of Tbilisi's sidewalks as infrastructure elicits shame and provokes debate about what constitutes the public good. ${ }^{8}$ As the car system's demands exceed the capacities of infrastructure constructed during the socialist 
era, the public/private distinction comes under stress in architectural zones like the sidewalk, spaces that have fallen outside the main foci of research on architecture and material culture. ${ }^{9}$

The sidewalk represents a crucial zone for ethnographic attention and anthropological theorization because it is the ground on which memories of past urbanisms accrue and claims to potential future urbanisms are staged. The case of Tbilisi epitomizes the contested status of the sidewalk, where certain social actors see it as a space for the growth of commerce and parking, whereas others are fighting to promote pedestrianism by restricting automobility. The idiom of personal freedom, which provided a rationale for the growth of automobile use, also forms the basis for activist contestations of the resultant car-crowded sidewalk space. Pedestrian activists describe the inferiority of Tbilisi street-and-sidewalk spaces with reference to what they imagine to be superior "European" modes of order, predicated on sharp boundaries. At the same time, they recognize that European cities, too, are struggling with automobility and its discontents. A new set of solutions must transcend, rather than recapitulate sharp divisions between what Fernando Rubio and Uriel Fogué $(2013$, 1037) have described as the political surface of human relations and domesticated nature, on the one hand, and the black-boxed subpolitical spheres of infrastructure, on the other. In Tbilisi, aspirations to pedestrianism risk appearing either as a return to a form of failed socialist modernity or as an anachronistic imitation of European modernity. Because pedestrianism does not have a clear political anchor in the Georgian context, it is a signifier with a mutable relationship to the utopian visions of socialism that the sidewalks in Tbilisi once served. Without a positive ideal, the pedestrian activist project lingers in contradiction: it is a campaign of hope conducted in the negative.

The present-day dismal friction of Tbilisi sidewalks is rooted in an uneasy relationship to twentieth-century state socialism, which incorporated many material and ideological elements from the nineteenth-century European liberal city. This included the street-and-sidewalk complex as a manifestation and index of modernity. Writing about the taken-for-granted dimensions of the logics of sidewalk infrastructure, the geographer Nicholas Blomley $(2011,36)$ argues that "pedestrianism" holds the facilitation of mobility as the self-evident rationale for the orderly sidewalk. ${ }^{10}$ He contends that pedestrianism, as a logic of circulation that focuses on the entanglements of people and things rather than primarily on the human subject, departs from the commitments of civic humanism that scholars of urbanism have mobilized for understanding the production, regulation, and 
evaluation of public spaces. Blomley $(2011,47)$ interprets the genealogy of the modern European and North American street-and-sidewalk complex in terms of fashioning a "nebulous collective end of the "public good," rather than of the individual liberal subject. Meanwhile, the historians Patrick Joyce (2003) and Chris Otter (2007), also working within frameworks that emphasize materiality and technology, have described how the Victorian city street enabled forms of governance and subjecthood. Developing and displaying civility in the Victorian city involved crafting "public spaces conducive to the exercise of clear, controlled perception: wide streets, squares, and parks" (Otter 2002, 3). Blomley's view is compatible with Joyce and Otter's arguments about liberal subjecthood in this crucial way: the design features of the modern liberal city can be mobilized by engineers and other municipal actors to generate an abstract principle (circulation) for an abstract collective (the public), while at the same time producing certain modes of liberal subjecthood. Pedestrianism, as a seemingly neutral, apolitical rationale for public space as a zone of circulation, can be mobilized to support differing concepts of the public good under socialism and modern liberalism. In Georgia, new impingements on pedestrian mobility have catalyzed discourses of entitlement about the use of public space, thereby prompting the specification of a previously nebulous public good. Rather than approach the issue through the lenses of legal dispute or expert discourse, I focus here on popular discourses about what has gone wrong with cars and sidewalks in Georgia and what might be done to set things right.

Contestation about how to reconcile the inheritances of the European liberal city and their refraction through socialist modernism has been a hallmark of the postsocialist order (Manning 2009a). The Georgian experience of liberal modernity, moreover, was filtered through socialist modernity (though the two are, as one reviewer of this article put it, "uncanny doppelgängers"). The sidewalk-andstreet infrastructure of contemporary Tbilisi is a product of socialist modernity, as the transport network was Soviet-made (Van Assche and Salukvadze 2013; Salukvadze and Golubchikov 2016). The organizing ideological principles of the neoliberal postmodern order in Georgia exhibit inheritances from liberalism, which enabled ruling through freedom (Joyce 2003) via technosocial affordances of a built environment that was organized around clear vision, movement, civility, and socialism. Under socialism, the inculcation of interior moral dispositions was achieved in part through the doctrine of kul'turnost' (culturedness), which offered a system of exterior, material forms allowing one to express one's civilized status and encompassing both private domestic spaces like apartments and public spaces 
like parks (Dunham 1990; Fitzpatrick 1992; Boym 1994, 102-106; Kelly and Volkov 1998; Volkov 2000). The forms and social meanings of kul'turnost' changed over time. Kul'turnost', as a "program for proper conduct in public" (Dunham 1990, 22), represented Soviet ways of displaying and interpreting the material world as expressive of moral qualities related to civilizational ideals. One of the postsocialist legacies of kul'turnost' was the notion that sidewalks, and the ways that one comported oneself on them, constituted symbols of a moral order. Kul'turnost' provided a template with which to understand diverse practices of consumption and comportment as constitutive of embodied civilizational modernity.

New corporeal competencies proved to be crucial components of urban space, as car and pedestrian instructional texts and warnings attest. The wide sidewalks that flank major avenues were once conducive to a pedestrian culture that embodied what Joyce (2003, 213-15) has termed "liberal walking."

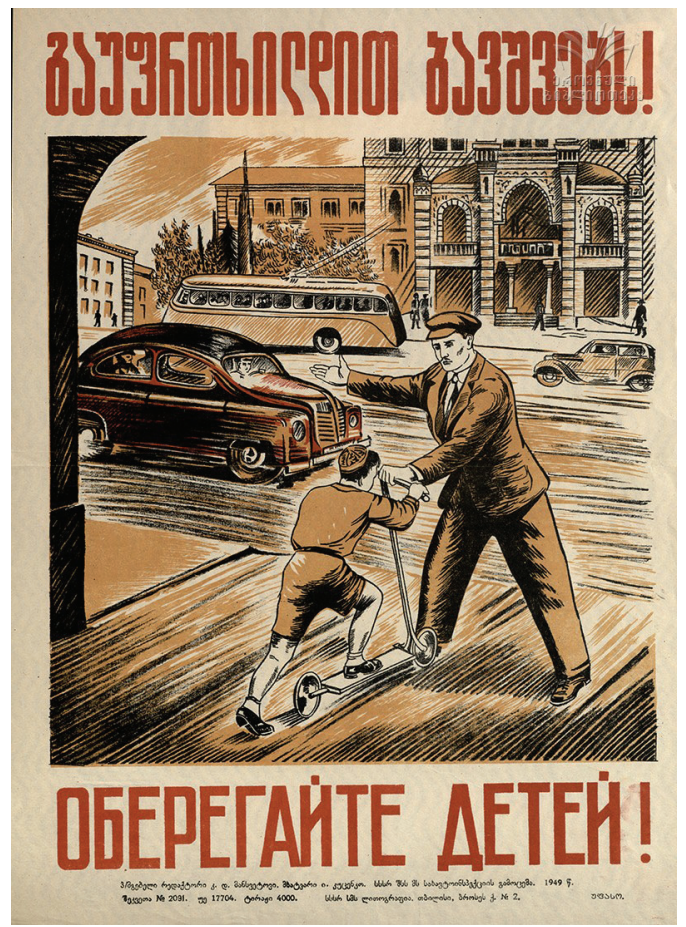

Figure 3. This 1949 poster reads: "Protect the children!” (Georgian: gauprtkhildit bavshvebs! Russian: oberegaite detei!). The man physically diverts the scooter-riding child away from the road and onto the sidewalk. A series of such street behavior posters focuses on instilling ruleand-norm-abiding behavior in drivers and pedestrians alike. Image by I. Kutsenko for the State Traffic Police, http://dspace.nplg.gov.ge/handle/1234/18315. 


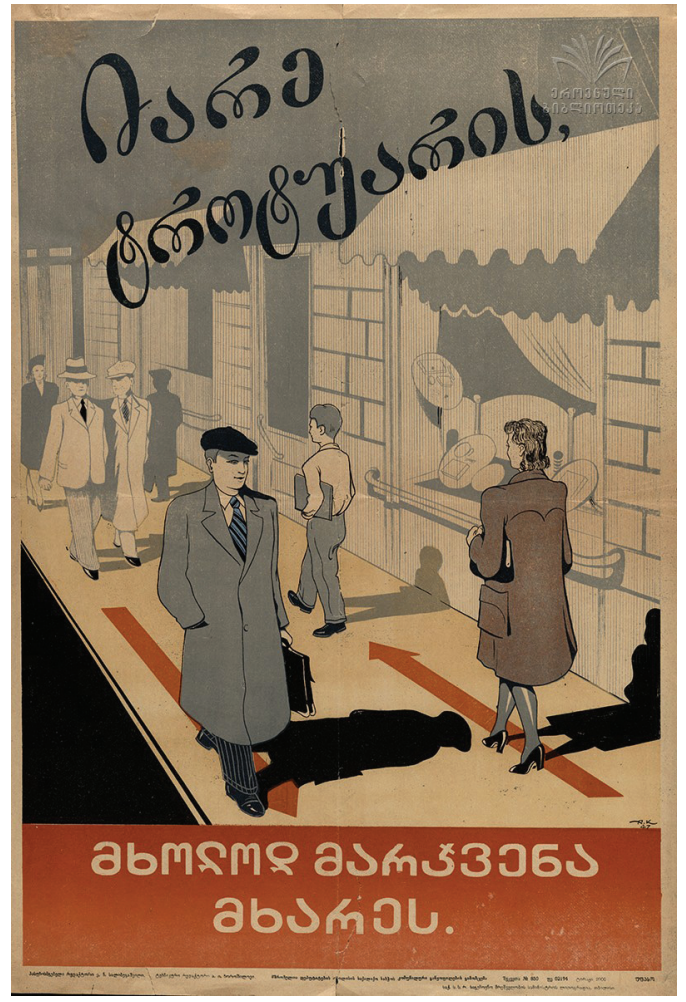

Figure 4. This 1947 poster reads: "Walk on the sidewalk, only on the right side." Pedestrian comportment was an object of state-directed instruction. Image by the City Council Utility Division, http://dspace.nplg.gov.ge/handle/1234/18040.

\section{TWENTY-FIRST-CENTURY SIDEWALK ORDERS}

The conditions of Tbilisi's present-day street-and-sidewalk system reflect an acceleration of investor urbanism, which has exacerbated and made visible tensions among different aspirations toward urban harmony. Many sidewalks operate according to a de facto model of shared space, one often experienced as dismal friction, reducing pedestrian enjoyment of the city. ${ }^{11}$ Wide sidewalks on Rustaveli Avenue, once intended to support a pedestrian culture, have now been overtaken by outdoor seating for restaurants and cafés. Elsewhere, as on Chavchavadze Avenue, sidewalks have provided the space for an expansion of the parking system. Cafés are potent symbols of the everyday infrastructures of sociability under modernity (Manning 2013). But installing a café does not suffice to ensure the creation of European-type sociality. Activities on the sidewalks outside cafés and other places of commerce also contribute to the forms of sociality that the city engenders. The Saakashvili-era government targeted merchants, as unwanted so- 
cial pollutants, for removal from public spaces like these (Rekhviashvili 2015). Outdoor seating for cafés, like automobile parking on sidewalks, can function either as a sign of affluence and freedom or of waste and selfishness. ${ }^{12}$ In Tbilisi, the perimeters of restaurants and roads have expanded, engulfing the sidewalk archipelagos that lie vulnerable between them.

The colonization of the sidewalk by cars has not occurred evenly throughout the city; instead, it has concentrated in areas of commerce. Certain areas of Tbilisi, including much of the downtown strip of Rustaveli Avenue and Davit Aghmashenebeli Avenue, are designed with physical barricades to prevent cars from invading the sidewalks. Davit Aghmashenebeli Avenue underwent major renovations beginning in 2010. Then president Sakashvili said about these renovations: “This area most resembles Paris, and we will make it look like Paris" (Kirtzkhalia 2010). The resemblance to Paris, however, remains purely aspirational. ${ }^{13}$ A more accurate analogy would be to Saint Petersburg, but Sakashvili's distaste for Russianness precluded such a comparison. Installing bollards that firmed up the boundaries of street and sidewalk was one element of the project intended to make Davit Aghmashenebeli Avenue look like Paris. Barricades include waist-high metal posts, elevated flowerbeds, and small trees. Such demarcation is modeled on an imagined European city in which the respective worlds of car and human remain clearly marked off from one another. When a recent renovation program on Davit Aghmashenebeli was finished in 2016, Prime Minister Giorgi Kvirikashvili remarked at the opening that "the price of the real estate has shot up fivefold . . . this will be one of the most attractive districts in Tbilisi for all tourists" (Georgia NewsDay 2016). The most carefully controlled pedestrian zones in Tbilisi are those that are intended to be tourist-friendly shopping areas. These zones are fashioned as European spaces conducive to orderly forms of commerce. Distinct conduits for pedestrian and automotive movement, with a backdrop of leisurely commerce, are interpreted as signs of Europeanness.

Within the ecology of transportation infrastructure in Tbilisi, another factor that has contributed to a predominance of cars is the class-linked devaluation of public transportation. In Tbilisi, many who have aspirations of upward mobility avoid public transportation, including metros, minibuses, and buses, in favor of private cars or taxis. One afternoon on Kostava Street, I counted as forty taxis drove by in one minute. The ubiquity of the taxi is connected to its special status as semipublic and semiprivate, symbolizing multiple forms of freedom, including commerce, movement, and distance from other commuters. Public transportation, including the metro, constitutes an infrastructure of public life in which 
there was considerable investment under socialism (Jenks 2000). In the postsocialist world, narratives about human potential have been tethered to transport, as Alaina Lemon $(2000,2015)$ has described in the forms of order and disorder attached to the Moscow metro. In Tbilisi, this has meant that the metro, as a socialist-era infrastructure, has diminished in status, having become associated with low social class as a consequence of an expanding car culture. As Inga Grdzelishvili and Roger Sathre $(2011,44)$ argue, based on a survey of more than three hundred transportation users in Tbilisi, combating the growth of an increasingly "car-oriented culture" depends on "making public transportation options competitive with the perceived advantages of the car."

\section{PARKING CHAOS AND CORPORATE ORDER}

Frustration, dissatisfaction, and shame emerge against the backdrop of largescale changes in the ways that a growing car culture has impacted street-andsidewalk order. For this reason, it is important to take stock of who controls parking in Tbilisi, and how public and governmental actors have assumed responsibility for sidewalk governance. Parking politics offer a lens onto disputes about the public good. In 2007, a private group called CT Park signed a contract to serve as the exclusive parking-management company in Tbilisi until 2022. The company's practices provoked public frustration and a new focus on the forms of authority governing street and sidewalk parking. Parking politics in Tbilisi also open a window onto contests for control among actors including the municipal government, CT Park, and a fleet of self-appointed parking attendants (st'aianshik'ebi) who direct cars into spots on the sidewalk and street for spare change. ${ }^{14}$ A holistic account of parking labor must take into account the uneven relationship between CT Park and the st'aianshik'ebi, who operate around, and at times within, the official zones of CT Park.

St'aianshik'ebi, who have existed in Tbilisi at least since the 1990s, represent an entrenched form of parking organization that operates alongside yet out of the control of the painted lines, metal signs, and ticketing mechanisms of CT Park. Because they manage to work alongside CT Park in a fashion that solves the immediate problem of where to put cars without creating new material infrastructure, st'aianshik'ebi have fallen outside of activist, political, and corporate concern. They are mediators, filling the gaps between multiple, overlapping systems and temporarily resolving the contradictions among them. ${ }^{15}$

In a pathbreaking article on the anthropology of parking, Liviu Chelcea and Ioana Iancu (2015) describe self-appointed parking attendants (parcagii) in the 


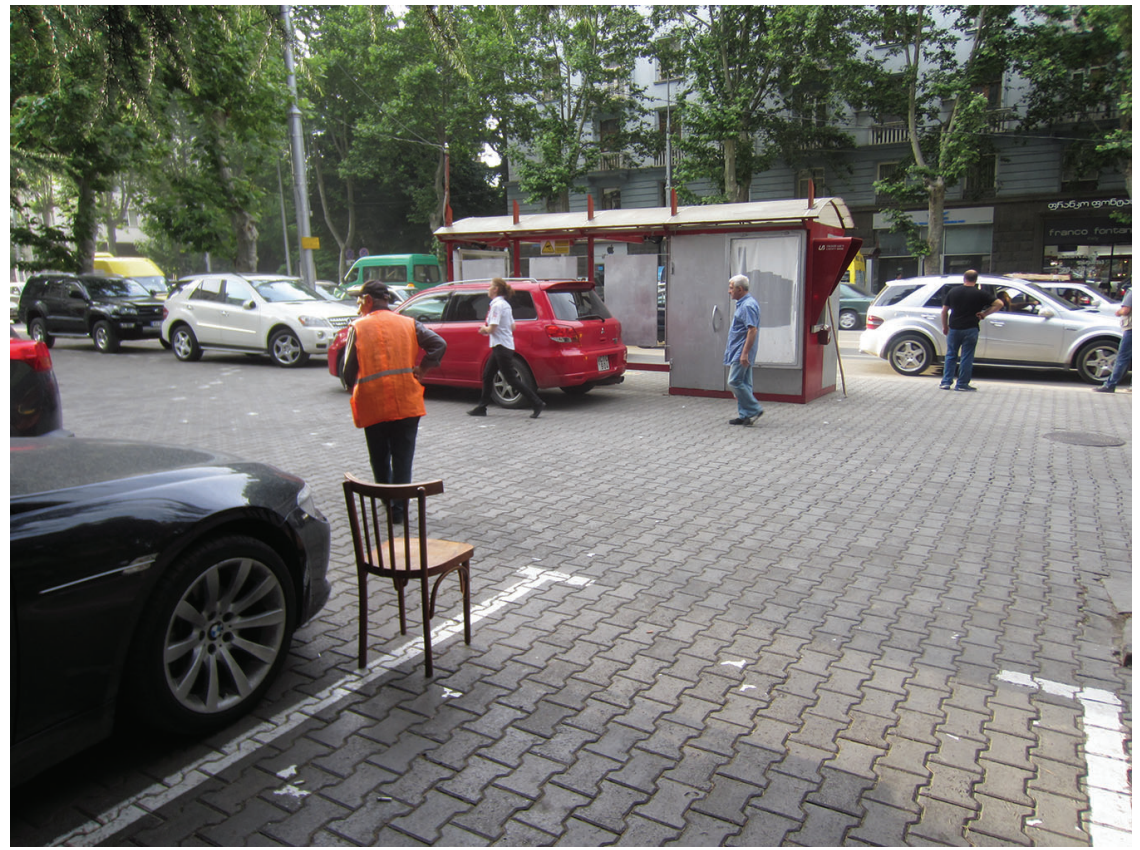

Figure 5. A self-appointed parking attendant at work, 2015. The three cars on the left are parked on the sidewalk in an area adjacent to Chavchavadze Avenue. Photo by Perry Maxfield Waldman Sherouse.

Romanian context, offering a portrait of parcagii as human laborers who function as infrastructure (cf. Simone 2004). Like the parcagii in Bucharest, st'aianshik'ebi in Tbilisi command a strip of pavement in areas of downtown that are tourist or work destinations - and hence car destinations. Attired in the weathered garments of the urban poor, they are identifiable by a bright neon sash or a loosely fitting neon vest. They often wield a white baton, modified with electrical tape or neon strips to enhance visibility. Their interactions with drivers consist primarily of directing drivers into empty parking spots, whether in makeshift lots on the sidewalk and edges of the street or in official CT Park spaces, after which they solicit donations in the form of spare change. Some English-speaking expatriates refer to st'aianshik'ebi as the "modi-men," because they say modi, modi! ("come, come!") to beckon drivers into free spots, particularly when apprehensive drivers in conditions of low visibility halt before backing up far enough. St'aianshik'ebi engage in other traffic services for regular customers, such as reserving spots and coordinating situations of double-parking or other parking maneuvers (cf. Chelcea and Iancu 2015, 66-67). Unlike in Bucharest, many of the self-appointed parking 
attendants in Tbilisi have a reputation for alcoholism, and it is not uncommon to find parking attendants who drink on the job.

Citizens as well as governmental officials have criticized CT Park. Aliko Elisashvili, a member of the city council, vocally reprimanded CT Park for the way the company has handled city parking. In 2014, Elisashvili even pursued an annulment of the city's contract with CT Park. Mayor Davit Narmania, who was elected in 2014 and served until November 2017, has also been critical of the company. ${ }^{16}$ In a television interview, Narmania asserted, for example, that CT Park profits from the chaotic parking culture in Tbilisi but does nothing to improve it. "I'll put it plainly," he said, "CT Park will not remain in Tbilisi for long." Yet canceling the contract with CT Park would cost an estimated 25 million Georgian lari (about US\$10 million), exceeding what the local budget can supply. City Hall has sought renegotiation on several points of the original contract, while stopping short of proposing an annulment. In January 2015, Mayor Narmania announced that a new multilevel parking structure would be built in Tbilisi, one that would serve as a competitor to CT Park. Speaking to a journalist, Narmania said: “As for City Park's fate, it currently remains unsettled” (Agenda.ge 2015). Later that year, the Georgian Parliament approved changes to parking laws that reduced the range of cases for which CT Park could tow vehicles.

A few months later, my friend $\mathrm{Ilia}^{17}$ and I conducted a telephone interview with a public relations representative from CT Park, Levan Tabidze. We inquired about why the organization had developed a negative reputation. Tabidze answered in this way:

First of all, there is no parking organization in the world where most people meet such an organization positively, as [such an organization] is associated with fines and taking cars away. It is associated with the negative. The kindness that this organization does nobody recognizes. . .. Let me give you a very simple example. I live in Vake. . .. I remember what chaos there was in my nearby street in terms of parking. Since CT Park entered the market and established the rule that cars can be parked on the left and not on the right, the traffic is more simplified now and is not so complicated. Even pedestrians, who can walk on the sidewalks normally nowadays, they don't remember this. . .. We must also take into account the situation in Georgia before. We drew a city map of Tbilisi and the plan of how and where to draw the parking lines, we planned the city, we put up the signsas for the [no parking] sign, there was none in the city. There were no 
parking methods, which we have nowadays. There was total chaos in the city, and nobody responded to it. We didn't have parking problems resolved over the years, we didn't have parking culture itself at all. There were no parking problems in the Soviet Union at all, and in the 1990s everything was ruined and complete chaos was set up. And from the 1990s up to 2007 the number of cars increased tenfold, and CT Park started to clean up this chaos.

Tabidze argued that parking problems did not exist in the Soviet Union. Once automobility intensified in the 1990s, CT Park stepped in to create parking order from "chaos." The swirl of public, activist, and governmental discontent with the "parking culture" promulgated by CT Park raised questions about its efficacy. Meanwhile, CT Park policed only the zones in which they had been granted jurisdiction. In many other parts of the city, cars roamed freely.

Right before we interviewed Levan, a neighbor called to let Ilia know that his car, which was illegally parked on an adjacent street, was being ticketed. When Ilia came back inside after moving the car, I asked him how the ticketing system worked. He showed me the online CT Park interface, where customers could check and pay for their fines. I noticed that his account had eight unpaid fines. When I asked about this, he remarked that he would never pay them. This reaction reminded me of what James Scott (1985) calls the "weapons of the weak," forms of everyday resistance available to the relatively powerless. Yet CT Park, as a private organization without widespread popular or governmental support, was also relatively powerless. Ilia did not consider the organization's authority over parking legitimate, and was unconcerned about the possibility of CT Park's retribution. He told me that CT Park mailed tickets in hard copy, but Ilia refused to accept the mail. The mailman understood Ilia's refusal and would simply return the CT Park tickets, indicating that the intended recipient was not home.

\section{THE STOPKHAM CAMPAIGN IN RUSSIA}

Georgian activists and politicians alike hold a Euro-normative conception of modernity as an aspirational target for Tbilisi, even if they may disagree on the forms its material infrastructures ought to take. For Georgian activists, Russian influence, even in the form of inspiration for social action, is undesirable in part because of associations with the Soviet past. Russia figures as a second-order version of modernity, and many distance themselves from deploying signs of Russianness, as they call up the history of hierarchy in which Georgia held a 
subordinate political and cultural position. In an example of this insistence on Georgian difference, a pedestrian rights organization called iare pekhit (literally, "go by foot") released a YouTube video in April 2015 that discussed the genesis and goals of their sidewalk social activism. ${ }^{18}$ In this video, called "vin aris Anonymous Georgian?" (Who is Anonymous Georgian?), a masked person called Anonymous Georgian introduces him or herself as a chveulebrivi mokalake (a regular citizen) and goes on to narrate the video in a low voice modulated to conceal the speaker's identity. ${ }^{19}$ Anonymous Georgian describes how the idea of putting flyers on cars arose as a reaction to the parking and traffic problems in Tbilisi. The speaker refers to another activist who curates an online repository of photos of drivers in violation of rules (the Facebook page is called gaitsanit samartskhvino mdzgholebi [meet shameless drivers]), and says that Anonymous Georgian had likewise begun making videos of drivers, even going so far as blocking cars from passing on the sidewalk. Then the narrator makes a connection to the practices of Stopkham in Russia: "When I said this idea [of blocking the sidewalk] loudly, someone sent me a link to Stopkham. Some also accused me of plagiarizing Stopkham, but that is not so. I heard about the existence of Stopkham at the end.”

What is Stopkham? In Russia, drivers have taken to the sidewalks to circumnavigate congested roads. The Stopkham (“Stop a Douchebag”) campaign began in Moscow in 2010. The group, founded by Dmitry Chugunov, is a governmentsponsored organization that spun off from the controversial pro-Kremlin youth movement Nashi. According to the journalist Eva Hartog (2016), Stopkham received about 18 million Russian rubles (US\$300,000) in federal grants between 2013 and 2015. The concept behind Stopkham is that a group of citizens prevent motorists from driving on sidewalks by physically standing in the way and then, if motorists persist, as they often do, affixing large stickers to their windshields. They also affix stickers to cars whose drivers violate other traffic regulations, such as double-parking or parking in inappropriate locations. The stickers say mne plevat' na vsekh / parkuyus' gde khochu (I don't care about others / I park where I want) or, for those driving on sidewalks, mne plevat' na vsekh / ezzhu kak khochu (I don't care about others / I drive how I want).

These encounters with so-called douchebags are video-recorded, edited with an electronic music soundtrack, and uploaded to YouTube. ${ }^{20}$ Aside from providing a valuable repository for students of Russian swearing (mat), these videos, some of which have millions of views, are demonstrations of a new form of vigilante justice in action. 


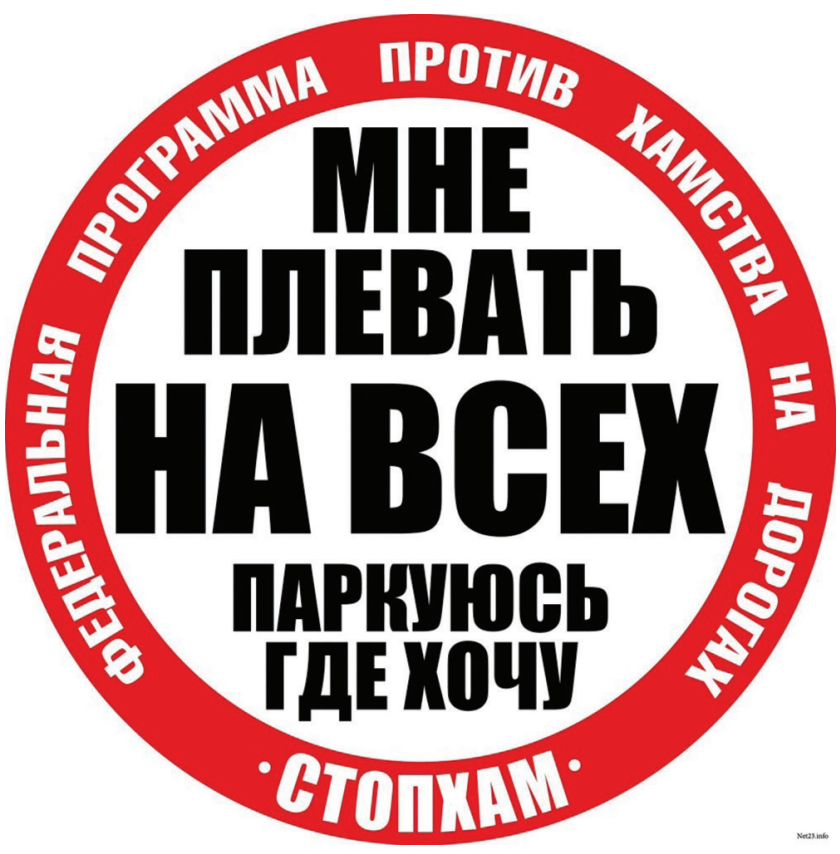

Figure 6. Stopkham sticker that reads: "I don't care about others / I park where I want." The text in the outer circle reads: "Federal Program Against Rudeness on the Roads." Image by Stopkham.

In addition to the entertainment value of these videos, the recordings also show how activists have intervened in public space to police the public/private divide. Upon discovering that the activists and the Stopkham stickers will not budge, drivers often scream that Stopkham is encroaching on their chastnaya sobstvennost' (private property) or, more simply, their sobstvennost' (property). The calculated indifference that members of Stopkham express at this sentiment reflects their mission to preserve the sidewalk as a domain for public, pedestrian movement. Their campaign assails the sanctity of the private vehicle by lacquering it with stickers. In a way, the Stopkham campaign refuses a nesting of the public and private. The same logic holds true for Stopkham antismoking videos, in which the activists extinguish pedestrians' cigarettes with a spray bottle, thereby refusing to acknowledge the smoker as freely passing through public space in a private bubble. They treat smoking as a violation of standards of publicness. The Stopkham campaign thus contests the rights of private properties to pass or waft through the public space of the sidewalk. ${ }^{21}$

This form of activism is noteworthy as much for its innovative use of social media as for its focus on the public/private distinction as a crucial site of societal 


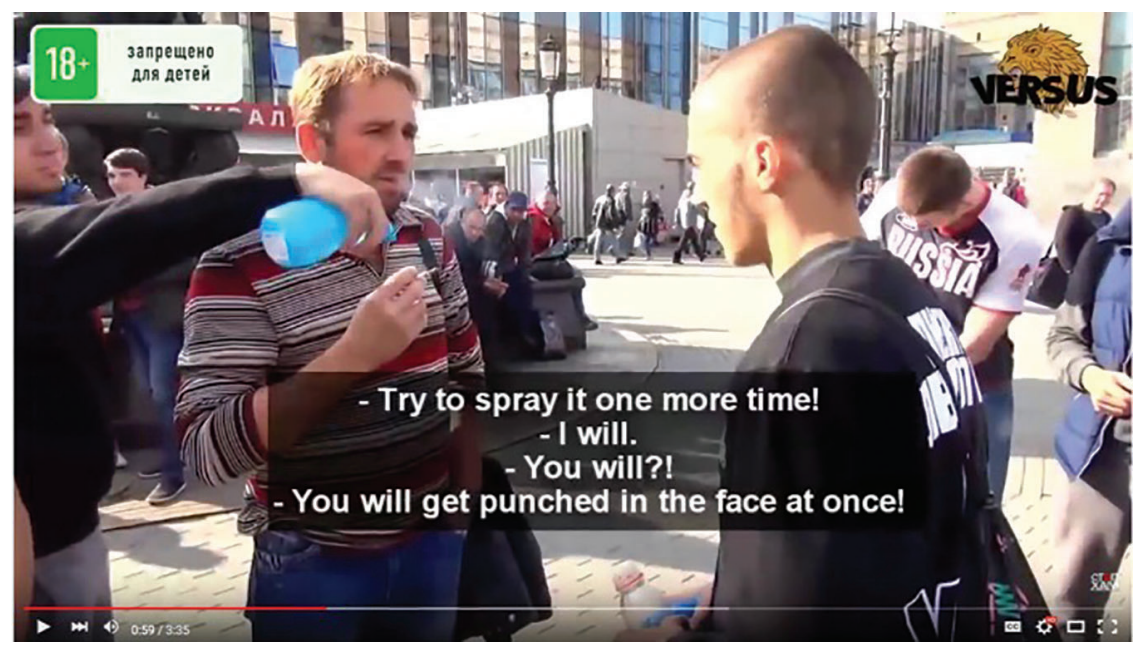

Figure 7. Still image from the video "Arrogant Smokers," in which activists extinguish smokers' cigarettes using a spray bottle. Image by Stopkham.

transformation. Though the teleology it presupposes is no longer from capitalist to socialist, the Stopkham campaign asserts boundaries between public and private property in ways that are reminiscent of earlier utopian projects of social transformation. ${ }^{22}$ For Stopkham, the target of transformation is renegade private property that rolls over curbs and down pedestrian paths. Such actions taken against private impingements on public space, however, should not be understood as reflecting a straightforward political position. Targeting the excesses of automobility, even if activists do not frame it in these terms, suggests that such excesses are the signs of a moral boundary has been crossed. ${ }^{23}$ Social actors who seek to transform urban parking culture by targeting excesses, through policy or advocacy, define modes of desirable (or adequate) urbanity in the process. The moral order that the Stopkham campaign asserts does not present a positive ideal, but mobilizes negative correctives against certain private behaviors that impinge on shared public space.

Such public shaming tactics raise the question: how are shame and freedom related in the liberal tradition of the city? Activists hope that shaming a douchebag driver will rebalance the pedestrian-versus-vehicle divide in a way that affords more freedom to the walking subject. But drivers, too, assert that their own freedoms are being impinged upon. In the Russian case, it is the state that restricts certain car freedoms in order to promote pedestrian freedoms. The Georgian state, by contrast, has ceded parking authority to CT Park, with poor results. 
With that, I return to the Georgian case to provide more detail on the contours of pedestrian activism and shame.

\section{EUROPEAN BOUNDARIES}

As the parking system expands, how do social actors envision new urban harmonies? In addition to being a generative topic of complaint in everyday conversation, the filling of sidewalk space with cars has also served as a point of critique for a variety of activist organizations. Here, I highlight the pedestrian rights organization iare pekhit. ${ }^{24}$ Challenging uses of sidewalk space in Georgia, as activists have increasingly done over the past decade, has involved redefining publicness through the figure of the pedestrian, whose ambulatory paths have faced a changing bevy of obstructions including other people. The primary tension that has come to the fore in protests is the conflicted cultural symbolism of the personal automobile: a sign of comfort and individual prosperity, but also of disregard for pedestrians and the environment. Signs of prosperity are impoverishing pedestrian life. As cars circulate along sidewalks, activists have concentrated their work on defining and policing the threshold where the sidewalk ends and the street begins.

To describe models of the city to which Tbilisi might aspire, social actors often refer to other real or imagined urban landscapes in the manner of collage, fashioning a discursive composite of places such as Barcelona, Shanghai, Berlin, and Paris, as if they possessed a common denominator. The templates of imagined order to which activists appeal discursively combine diverse postmodern cities into a placeless modern composite, for which the car-free walking subject constitutes the centerpiece of urban life. In one example, Elene Margvelashvili, the then leader of iare pekhit, said in an interview that she wanted to meet Enrique Peñalosa, the mayor of Bogotá, Colombia, because in her view Peñalosa had managed to change public perception of pedestrian rights. ${ }^{25}$ Government officials and activists alike positioned Tbilisi uneasily amid a palette of eclectic, incommensurate modern elsewheres. Later in the same interview, when asked what her dream is for iare pekhit, Margvelashvili replied:

A city that fosters human dignity and respect, development, a sense of freedom. But a sense of freedom that stands a lot higher than your personal freedom. A sense of a community, equality, and just, you know, a cool city, where you really do enjoy your time outside. Because I miss this so much that sometimes I just want to rush out of Tbilisi and go to somewhere like 
Berlin where I can just lie down in a big park and just enjoy my day, which is something impossible in Tbilisi today. So yeah, European city [laughs].

Here, Margvelashvili simultaneously invests Tbilisi with aspirational resemblances to Bogotá and Berlin. ${ }^{26}$ In another interview, in response to a question about how people can help, Margvelashvili replied that what her organization needed was "foreign experience." 27 She went on:

Many countries in Europe have managed to convince their government and managed to stop this unbreakable cycle of turning cities into places not for humans but for something else, for making money, for business, for prosperity of higher levels, for higher-income people and communities.

The sentiment that cities are turning into environments hospitable only to businesses, not people, serves as a reminder that iare pekhit centers the pedestrian in its reimagining of the street. Margvelashvili's concern that Tbilisi was becoming a city "for making money" rather than one for "humans" also contained a critique of emergent class divisions. The relationship between pedestrian life and class divisions begs the question of how organizations like iare pekhit deal with the legacy of the Soviet past, as the Soviet reformulation of public space was also intended to disrupt class divisions. Margvelashvili's solution was to selectively borrow from the Soviet past, rather than framing it as a nostalgic ideal. In the earlier interview, she simultaneously praised and criticized the Soviet experience for imbuing and depriving citizens of a "sense of community":

This sense of community, which should be there, because the Soviet Union was actually very community-oriented, is not there. Because what the Soviet Union, I think, killed in our community is the sense that one person is responsible for the common good, and can actually contribute to the common good. This understanding was not there because everything belongs to everybody, and this responsibility of every single person to do something for the general development, for the general well-being, is not there. So this is where education should come in, and this sense of, you know, civic engagement, civic responsibility, the responsibility of every person to do good, not just in terms of pedestrian issues.

Margvelashvili does not provide an explanation of what the problem with the "community-oriented" Soviet Union was. Instead, she uses the Soviet era as a reference point to discuss the personal and community responsibility that edu- 
cation must address. The class politics of this vision for freedom and responsibility in urban space remain unclear. Perhaps she meant to suggest that the Soviet experience valued the right thing ("community") but in the wrong way, or with the wrong effects. Referring to an array of urban places that have supposedly achieved a higher level of civilizational modernity than Tbilisi also served as a way to describe Georgia's capital in terms of a state of comparative lack. Even though Margvelashvili's comparisons included urban centers in South America and Asia, she nevertheless referred to these places with the shorthand of "European." It is as though Europe were a roulette wheel on which it would be a privilege for Georgia to fall, regardless of the particular tile.

Redescriptions of an idealized past often form the basis for claims about future political trajectories (Gotfredsen 2014; Khalvashi 2015). As Katrine Bendtsen Gotfredsen (2014, 251) has discussed, under Saakashvili, an unambiguous rhetoric of development and prosperity was constructed as an antithesis to the Soviet past. Preindustrial, Soviet modernist, and capitalist European forms served as reference points in narratives about clashes of values in the present. In Tbilisi, pedestrianism is not a return to an imagined harmonious past, but a new mode of order resonant with European forms. Reasserting boundaries, which activists imagine as a form of European order, stands as a mode of anachronistic imagining-but one without a clear relationship to the Soviet past.

A variety of other organizations in addition to iare pekhit are invested in so-called eco-urbanism in Tbilisi, harboring broad agendas for political and social change. My final example comes from a group called aighe kalaki ("take the city"), which promoted the construction of planters as makeshift sidewalk bollards. The group created a YouTube instructional video in which they describe how to craft bollards from car tires. In the video, group members fabricate bollards on Tbilisi streets with a portable lamp illuminating their work in the dark. This type of time-consuming DIY intervention straddles art and utility. The video ends with a shot of the completed bollards, standing on an otherwise empty sidewalk. Superimposed text reads daik'ave q'vela t'rot'uari! (Occupy all the sidewalks!). Like the Anonymous reference in the campaign by iare pekhit, this form of Occupy-style messaging links sidewalk politics to international protest movements. Tires filled with potted plants are more than barriers to cars: their digital representations are signs of belonging in an era of mediatized protest. 


\section{CONCLUSION: Walking into Modernity}

The public shaming tactics that I have described - campaigns insisting that SUV drivers have small penises, or posting pictures of instances of rude driving and parking online, or extinguishing cigarettes with spray bottles - are intended to catalyze self-regulation on the part of their targets. They form part of a broader moral policing of how automobility has allowed public space to become invaded by a swarm of mobile metal private spheres. Self-regulation is taken as the mark of a modern, ethical liberal subject, as well as its socialist twin. Another aspect of the use of such tactics, however, is that they are designed to catalyze an affective response, and in doing so, to function as a means of exerting power over the target. As performative acts, such shaming tactics may accomplish a wide variety of ends, including occupying, insulting, threatening, and refusing. While shaming campaigns may generate reflection on the boundaries of acceptable public comportment, the more immediate activist goal is to generate attention and discomfort. Martha Nussbaum (2004, 15) describes shame as "normatively unreliable" as a punitive measure, in part because of the indeterminacy of its effects on subjects. ${ }^{28}$ In the context of social activism, though, the indeterminacy of shame's effects can be beneficial insofar as the goal is to stir up sentiments, rather than to settle new norms of behavior.

In Tbilisi, emerging contests over parking demonstrate how local actors make sense of the aesthetic and economic conditions of urban lack. In response to the erosion of sidewalk boundaries, shame, as the "affect of indignity, of defeat, of transgression, and of alienation" (Tomkins 1995, 133), occupies a primary position. One reason for this is that shame emerges in situations of unmet ideals. It operates, as Tamta Khalvashi (2015) has described, as a diffuse but pervasive affect in conditions of peripherality. Activists throughout the world wield shame as an instrument of social change; what is specific to the case of urban Georgia, though, is that shame, as a discursive hinge, joins dimensions of inferiority that exceed a singular politics and do not coalesce into a program with a positive ideal. Rather than offering a cultural-psychological explanation for the appearance of certain affects, then, I have focused in this article on how a series of interrelated conditions shape the particular contours and transformations of shame in urban postsocialist activism. As precipitated in encounters with material infrastructure, shame articulates a sense of comparative lack. In turn, activists minimize their experience of this negative affect by redirecting it toward inconsiderate drivers, thereby converting it into a tool of public good. Restoring or preserving the pedestrian function of the sidewalk is framed as a way to keep civility and personal 
dignity intact. Without a consensus about the ideal form of public good or an agreed-upon balance among logics of automobility, pedestrianism, and public transportation, a circuit of negative affect remains open. The lack of consensus about the shape of the public good remains an underlying cause of the dismal friction of Tbilisi's urban condition. Pedestrian activists' rhetoric about the desirability of European boundaries animates unfulfilled modernist dreams and, in so doing, draws attention to the irreparable gaps between the promises of urbanism and the practical realities of investor urbanist development. Furthermore, such rhetoric signals an ambivalence about the meanings of collective and material life in European modernity, encompassing nineteenth-century ideals of pedestrianism and their afterlives.

\begin{abstract}
In recent years, cars have steadily colonized the sidewalks in downtown Tbilisi. By driving and parking on sidewalks, vehicles have reshaped public space and placed pedestrian life at risk. A variety of social actors coordinate sidewalk affairs in the city, including the local government, a private company called CT Park, and a fleet of self-appointed st'aianshik' ebi (parking attendants) who direct drivers into parking spots for spare change. Pedestrian activists have challenged the automotive conquest of footpaths in innovative ways, including art installations, social media protests, and the fashioning of ad hoc physical barriers. By safeguarding sidewalks against cars, activists assert ideals for public space that are predicated on sharp boundaries between sidewalk and street, pedestrian and machine, citizen and commodity. Politicians and activists alike connect the sharpness of such boundaries to an imagined Europe. Georgia's parking culture thus reflects not only local configurations of power among the many interests clamoring for the space of the sidewalk, but also global hierarchies of value that form meaningful distinctions and aspirational horizons in debates over urban public space. Against the dismal frictions of an expanding car system, social actors mobilize the idioms of freedom and shame to reinterpret and repartition the public/private distinction. [infrastructure; shame; pedestrianism; parking culture; sidewalks; Georgia; postsocialism]
\end{abstract}

\title{
NOTES
}

Acknowledgments Thanks to Maria Abascal, Florian Biermann, Dominic Boyer, Elsa Devienne, Dana Graef, Michelle Jurkovich, Alaina Lemon, Tony Levitas, Paul Manning, Casey Miller, Sue Petersen Nedved, Serguei Oushakine, Bridget Purcell, Emily Wilson, the Brown University Department of Anthropology Lunchtime Colloquium participants, and five anonymous reviewers for Cultural Anthropology.

1. See Hartblay 2017 on practices and discourses around disability access in Russia.

2. Fountains, especially those equipped with amplified music boxes, came to be emblematic features of the urban development that Saakashvili promoted during his presidency (2004-2013). In front of the Concert Hall, for example, a large fountain decorated 
with a painting of a red rose had been installed. Paul Manning (2009b, 927) argues that the Rose Revolution formed a "culture of erasure, in which western capitalist brands were deployed to banish, once and for all, the last vestiges of socialism." This erasure was a precondition for the material inscription of a European orientation, which, in turn, was to influence "mentality" (cf. Jones 2006; Curro 2015). For further discussion of the Rose Revolution, see Manning 2007 and Jones 2012.

3. I follow the Apridonidze system of transliteration for Georgian to English, except in the case of personal names and other proper nouns, for which I leave off the diacritic markers in the English transliteration. All translations of Georgian and Russian are my own unless otherwise noted.

4. I follow Silvan Tomkins's (1995) conceptualization of affect as a motivational system that operates alongside the drives.

5. In Georgia, everyday interactions with the car system reflect the consequences of poverty. In neighboring Azerbaijan, by contrast, the uneven consequences of renovation and hyperbuilding are objects of scrutiny in making sense of aesthetic and economic surplus and its discontents (Grant 2014).

6. Lutz and Lutz Fernandez (2010, xi) define the car system as "a mix of industry, infrastructure, land use, governmental activity, consumer behavior, and habitual processes of daily travel." I use the terms car system and automobility interchangeably in this article.

7. Penny Harvey and Hannah Knox (2015, 3), in comparison, analyze roads as a mundane infrastructure that allow us to "register histories and expectations of state presence and state neglect."

8. On networked infrastructure and technological mobilities, see Graham and Marvin 2001.

9. Scholarship on the links between socialist material culture and ideology has found distinctive footholds either in inner domestic spaces, with housing serving as a preeminent example (see Humphrey 2005), or in the construction of monumental public forms like statues. When semipublic spaces, such as the corridor or courtyard, appear in analyses of socialist and postsocialist architectural forms, they are often positioned as buffer zones between the inner realm of the communal apartment and the outer realm of the public street. Susan Gal (2002) has observed that the public/private distinction constitutes a malleable, shifting mode of oppositions.

10. Blomley's concept of pedestrianism is not to be confused with competitive speed-walking, a sport popular in the nineteenth century that went by the same name. For an account of recent scholarly work on the social practice of walking, see Lorimer 2011.

11. Shared space is a "traffic engineering concept that eliminates physical barriers separating motor vehicles, pedestrians, and other road users to facilitate a sharing of street space" (Imrie 2012, 2261). This design model has negative consequences for vision-impaired populations (Imrie 2012; Sánchez Criado and Cereceda Otárola 2016). As the scholars of urban planning Anastasia Loukaitou-Sideris and Renia Ehrenfeucht $(2009$, 33) have observed, historically, the figure of the pedestrian has been equated with the public, a process that characterized by social exclusion.

12. For a history of the Soviet automobile, including its cultural symbolism, see Siegelbaum 2008.

13. For Georgian modernist conceptions of Paris as an incarnation of the fantastic Western European urban cosmopolitan wished-for homeland, see Manning 2013.

14. The Georgian term st'aianshik'ebi is a calque from the Russian stoyanshchiki, formed from the noun stoyanka (parking).

15. My use of the term mediator echoes Bruno Latour's (1993, 77-78) opposition between intermediaries, which simply "transfer, transport, and transmit," and the mediator, which is an "original event and creates what it translates as well as the entities between which it plays the mediating role." Latour revisits the intermediary/mediator division in Reassembling the Social, where he explains that mediators effect transformations (in meaning) while intermediaries do not: they simply "transport" it (Latour 2015, 39).

16. The newly elected mayor Kakha Kaladze has also spoken out about ongoing public 
concern over CT Park's practices and their overall effect on Tbilisi's parking culture (Morrison 2017).

17. This is a pseudonym selected by the informant. All other names in this article are real.

18. The video is available on YouTube at https://www.youtube.com/watch?v $=$ Nt6FMYG4p4.

19. On the organization Anonymous and its links to protest, social activism, and hacking, see Coleman 2014.

20. The English-language channel is no longer available, but the Russian-language channel is available as of this writing at https://www.youtube.com/user/stopxamlive.

21. The fate of the Stopkham movement, however, has grown uncertain as participants have enforced traffic laws against political elites, rather than exempting them (Hartog 2016).

22. Susan Gal $(2002,86)$ points out that the "public/private distinction was . . . directly targeted by communist theorists in the nineteenth century - and by Soviet and, later, East Central European communist parties - as essential points for transforming bourgeois, capitalist society through social engineering."

23. On the concept of excess, see Phillips 2010.

24. Iare pekhit was founded by an American named Mark Mullen. In June 2015, I spoke with him about the genesis and goals of the organization. He believed that without the consistent enforcement of parking rules, the problem of sidewalk drivers would remain. Mullen was optimistic that a zero-tolerance policy would fix the traffic problems of Tbilisi. By way of analogy, he described the seat-belt regulation, championed by Vano Merabishvili (minister of internal affairs from 2004 to 2012) as an example of a zerotolerance policy that created rapid social change. Prior to the regulation, almost no one in Georgia wore a seat belt, but within a matter of weeks, that changed because drivers and passengers were fined 40 lari (about $\$ 15$ at the time) for not doing so. Nevertheless, cultural obstacles to seat-belt use exist, as refusing a seat belt may be read as a sign of masculinity (Matosyan 2009).

25. The video is available at https://www. youtube.com/watch?v=E7cyeTr8AAU.

26. Note that this perspective flattens the ongoing urban modernization histories of each city. For a post-Haussmannian perspective on urban political ecologies, see Rubio and Fogué 2013.

27. The video is available at https://www.youtube.com/watch?v=OuoAwBT9QSg.

28. Nussbaum $(2004,15)$ argues that within the context of liberal democracies, there is a variety of reasons "to inhibit shame and protect [liberal society's] citizens from shaming" as a punitive measure. Nussbaum's perspective on the use of public shaming is informed by her commitment to political and legal systems that promote human dignity and mutual respect among citizens. For this reason, she favors penalties that promote "reparation and reintegration" (Nussbaum 2004, 233).

\section{REFERENCES}

Agenda.ge

2015 "Multilevel Parking System Planned for Tbilisi, Says Mayor.” News, January 8. Berman, Marshall http: / /agenda.ge/news/27602/eng.

1982 All That Is Solid Melts into Air: The Experience of Modernity. New York: Simon and Schuster.

Blomley, Nicholas

2011 Rights of Passage: Sidewalks and the Regulation of Public Flow. New York: Routledge. Boym, Svetlana

1994 Common Places: Mythologies of Everyday Life in Russia. Cambridge, Mass.: Harvard University Press.

Chelcea, Liviu, and Ioana Iancu

2015 "An Anthropology of Parking: Infrastructures of Automobility, Work, and Circulation." Anthropology of Work Review 36, no. 2: 62-73. https://doi.org/ 10.1111/awr. 12068 . 
Coleman, Gabriella

2014 Hacker, Hoaxer, Whistleblower, Spy: The Many Faces of Anonymous. New York: Verso. Curro, Costanza

2015 "Davabirzhaot! Conflicting Claims on Public Space in Tbilisi Between Transparency and Opaqueness." International Journal of Sociology and Social Policy 35, nos. 7-8: 497-512. https://doi.org/10.1108/IJSSP-12-2014-0122.

Duneier, Mitchell

1999 Sidewalk. New York: Farrar, Straus, and Giroux.

Dunham, Vera

1990 In Stalin's Time: Middleclass Values in Soviet Fiction. Durham, N.C.: Duke University Press.

Fitzpatrick, Sheila

1992 The Cultural Front: Power and Culture in Revolutionary Russia. Ithaca, N.Y.: Cornell University Press.

Frederiksen, Martin Demant

2012 “A Gate, but Leading Where?': In Search of Actually Existing Cosmopolitanism in Post-Soviet Tbilisi." In Post-Cosmopolitan Cities: Explorations of Urban Coexistence, edited by Caroline Humphrey and Vera Skvirskaja, 120-40. New York: Berghahn.

Gal, Susan

2002 “A Semiotics of the Public/Private Distinction." differences 13, no. 1: 77-95. https: / / doi.org/10.1215/10407391-13-1-77.

Georgia NewsDay

2016 "Prime Minister Opened the Renovated David Aghmashenebeli Avenue." Society, September 26. http://newsday.ge/new/index.php/en/component/ k2/item/24962-prime-minister-opened-the-renovated-david-aghmashenebeliavenue.

Goldstein, Daniel M.

2016 Owners of the Sidewalk: Security and Survival in the Informal City. Durham, N.C.: Duke University Press.

Gotfredsen, Katrine Bendtsen

2014 "Void Pasts and Marginal Presents: On Nostalgia and Obsolete Futures in the Republic of Georgia." Slavic Review 73, no. 2: 246-64. https://doi.org/ 10.5612/slavicreview.73.2.246.

Graham, Stephen, and Simon Marvin

2001 Splintering Urbanism: Networked Infrastructures, Technological Mobilities, and the Urban Condition. New York: Routledge.

Grant, Bruce

2014 "The Edifice Complex: Architecture and the Political Life of Surplus in the New Baku.” Public Culture 26, no. 3: 501-528. https://doi.org/10.1215/089923632683648.

Grdzelishvili, Inga, and Roger Sathre

2011 "Understanding the Urban Travel Attitudes and Behavior of Tbilisi Residents." Transport Policy 18, no. 1: 38-45. https://doi.org/10.1016/j.tranpol.2010. 05.006.

Hartblay, Cassandra

2017 "Good Ramps, Bad Ramps: Centralized Design Standards and Disability Access in Urban Russian Infrastructure.” American Ethnologist 44, no. 1: 9-22. https://

Hartog, Eva doi.org/10.1111/amet. 12422 .

2016 “A Kremlin Youth Movement Goes Rogue.” Moscow Times, April 8. https:// themoscowtimes.com/articles/a-kremlin-youth-movement-goes-rogue- 52435 .

Harvey, Penny, and Hannah Knox

2015 Roads: An Anthropology of Infrastructure and Expertise. Ithaca, N.Y.: Cornell University Press. 
Holston, James

1999 "The Modernist City and the Death of the Street." In Theorizing the City: The New Urban Anthropology Reader, edited by Setha M. Low, 245-76. New Brunswick, Humphrey, Caroline

N.J.: Rutgers University Press.

2005 "Ideology in Infrastructure: Architecture and Soviet Imagination." Journal of the Royal Anthropological Institute 11, no. 1: 39-58. https://doi.org/10.1111/j. 1467-9655.2005.00225.x.

Imrie, Rob

2012 “Auto-Disabilities: The Case of Shared Space Environments." Environment and Planning A 44, no. 9: 2260-77. https://doi.org/10.1068/a44595.

Jacobs, Jane

1961 The Death and Life of Great American Cities. New York: Vintage.

Jenks, Andrew L.

2000 "A Metro on the Mount: The Underground as a Church of Soviet Civilization." Technology and Culture 41, no. 4: 697-724. https://doi.org/10.1353/tech. 2000.0160 .

Jones, Stephen F.

2006 “The Rose Revolution: A Revolution Without Revolutionaries?” Cambridge Review of International Affairs 19, no. 1: 33-48. https://doi.org/10.1080/ 09557570500501754.

2012 Georgia: A Political History since Independence. New York: I. B. Tauris.

Joyce, Patrick

2003 The Rule of Freedom: Liberalism and the Modern City. New York: Verso.

Kelly, Catriona, and Vadim Volkov

1998 “Directed Desires: Kul'turnost' and Consumption.” In Constructing Russian Culture in the Age of Revolution, 1881-1940, edited by Catriona Kelly and David Shepherd, 291-313. New York: Oxford University Press.

Khalvashi, Tamta

2015 "Peripheral Affects: Shame, Publics, and Performance on the Margins of the Republic of Georgia.” PhD dissertation, University of Copenhagen.

Kim, Annette Miae

2015 Sidewalk City: Remapping Public Space in Ho Chi Minh City. Chicago: University of Chicago Press.

Kirtzkhalia, Nana

2010 "Georgian President: Tbilisi Prospect Aghmashenebeli to Resemble Paris Streets.” Trend News, January 29. https://en.trend.az/azerbaijan/politics/ 1628787.html.

Latour, Bruno

1993 We Have Never Been Modern. Translated by Catherine Porter. Cambridge, Mass.: Harvard University Press. Originally published in 1991.

2015 Reassembling the Social: An Introduction to Actor-Network Theory. New York: Oxford University Press.

Lemon, Alaina

2000 “Talking Transit and Spectating Transition: The Moscow Metro." In Altering States: Ethnographies of Transition in Eastern Europe and the Former Soviet Union, edited by Daphne Berdahl, Matti Bunzl, and Martha Lampland, 14-39. Ann Arbor: University of Michigan Press.

2015 "MetroDogs: The Heart in the Machine." Journal of the Royal Anthropological Lorimer, Hayden Institute 21, no. 3: 660-79. https: //doi.org/10.1111/1467-9655.12246.

2011 "Walking: New Forms and Spaces for the Study of Pedestrianism." In Geographies of Mobilities: Practices, Spaces, Subjects, edited by Tim Cresswell and Peter Merriman, 19-33. Burlington, Vt.: Ashgate. 
Loukaitou-Sideris, Anastasia, and Renia Ehrenfeucht

2009 Sidewalks: Conflict and Negotiation over Public Space. Cambridge, Mass.: MIT Press. Lutz, Catherine

2014 "Cars and Transport." In A Companion to Urban Anthropology, edited by Donald M. Nonini, 142-53. Malden, Mass.: John Wiley and Sons.

Lutz, Catherine, and Anne Lutz Fernandez

2010 Carjacked: The Culture of the Automobile and Its Effect on Our Lives. New York: Palgrave Macmillan.

Manning, Paul

2007 "Rose-Colored Glasses? Color Revolutions and Cartoon Chaos in Postsocialist Georgia." Cultural Anthropology 22, no. 2: 171-213. https://doi.org/10.1525/ can.2007.22.2.171.

2009a "The City of Balconies: Elite Politics and the Changing Semiotics of the PostSocialist Cityscape." In City Culture and City Planning in Tbilisi: Where Europe and Asia Meet, edited by Kristof Van Assche, Joseph Salukvadze, and Nick Shavishvili, 71-102. Lewiston, N.Y.: Edwin Mellen Press.

2009b "The Epoch of Magna: Capitalist Brands and Postsocialist Revolutions in Georgia.” Slavic Review 68, no. 4: 924 45. https://doi.org/10.1017/ S003767790002458X.

2013 "The Theory of the Café Central and the Practice of the Café Peripheral: Aspirational and Abject Infrastructures of Sociability on the European Periphery." In Café Society, edited by Aksel Tjora and Graham Scrambler, 43-65. New York: Palgrave Macmillan.

Matosyan, Tigran

2009 "Killer Seat Belts, Feminine Drivers, and Tinted Windows: Pitfalls on the Way of Enforcement of Seat Belt Rules in Armenia." Report. Yerevan, Armenia: Caucasus Research Resource Centers.

Morrison, Thea

2017 “Tbilisi City Hall to Start Legal Dispute against City Park Company." Georgia Today, November 10. http://georgiatoday.ge/news/8143/Tbilisi-City-Hall-toStart-Legal-Dispute-against-City-Park-Company.

Nussbaum, Martha

2004 Hiding from Humanity: Disgust, Shame, and the Law. Princeton, N.J.: Princeton University Press.

Otter, Chris

2002 "Making Liberalism Durable: Vision and Civility in the Late Victorian City." Social History 27, no. 1: 1-15. https://doi.org/10.1080/03071020110094174.

2007 “Making Liberal Objects: British Techno-Social Relations, 1800-1900.” Cultural Studies 21, nos. 4-5: 570-90. https://doi.org/10.1080/09502380701278962. Phillips, Adam

2010 "Five Short Talks on Excess." In On Balance, 1-48. New York: Farrar, Straus, and Giroux.

Rekhviashvili, Lela

2015 "Marketization and the Public-Private Divide: Contestations between the State and the Petty Traders over the Access to Public Space in Tbilisi." International Journal of Sociology and Social Policy 35, nos. 7-8: 478-96. https://doi.org/ 10.1108/IJSSP-10-2014-0091.

Rubio, Fernando Domínguez, and Uriel Fogué

2013 "Technifying Public Space and Publicizing Infrastructures: Exploring New Urban Political Ecologies through the Square of General Vara del Rey." International Journal of Urban and Regional Research 37, no. 3: 1035-52. https://doi.org/ $10.1111 / 1468-2427.12052$.

Salukvadze, Joseph, and Oleg Golubchikov

2016 "City as a Geopolitics: Tbilisi, Georgia-A Globalizing Metropolis in a Turbulent Region.” Cities 52: 39-54. https://doi.org/10.1016/j.cities.2015.11.013. 
Sánchez Criado, Tomás and Marcos Cereceda Otárola

2016 "Urban Accessibility Issues: Techno-Scientific Democratizations at the Documentation Interface.” City 20, no. 4: 619-36. https://doi.org/10.1080/ 13604813.2016.1194004.

Scott, James C.

1985 Weapons of the Weak: Everyday Forms of Peasant Resistance. New Haven, Conn.: Yale University Press.

Siegelbaum, Lewis H.

2008 Cars for Comrades: The Life of the Soviet Automobile. Ithaca, N.Y.: Cornell University Press.

Simone, AbdouMaliq

2004 "People as Infrastructure: Intersecting Fragments in Johannesburg." Public Culture 16, no. 3: 407-429. https://doi.org/10.1215/08992363-16-3-407.

Tomkins, Silvan

1995 "Shame-Humiliation and Contempt-Disgust." In Shame and Its Sisters: A Silvan Tomkins Reader, edited by Eve Kosofsky Sedgwick and Adam Frank, 133-78. Durham, N.C.: Duke University Press.

Urry, John

2004 “The 'System' of Automobility." Theory, Culture and Society 25, nos. 4-5: 2539. https://doi.org/10.1177/0263276404046059.

Van Assche, Krisof, and Joseph Salukvadze

2013 "Tbilisi: Urban Transformation and Role Transformation in the Post-Soviet Metropolis.” In Remaking Metropolis: Global Challenges of the Urban Landscape, edited

Vardosanidze, Vladimir by Edward A. Cook and Jesus J. Lara, 86-102. New York: Routledge.

2003 "Urban Transport in Tbilisi (Georgia): Traits for the Portrait of Chaos." Paper presented at the Workshop on Sustainable and Healthy Urban Transport and Planning, Nicosia, Cyprus, November 16-18. https://www.unece.org/ fileadmin/DAM/thepep/en/workplan/urban/urban_docs.htm.

2009 "Social Dimensions of Urban Development in Post-Soviet Georgia: The Quest for Participatory Planning in Shattered Social Landscapes." In City Culture and City Planning in Tbilisi: Where Europe and Asia Meet, edited by Kristof Van Assche, Joseph Salukvadze, and Nick Shavishvili, 189-208. Lewiston, N.Y.: Edwin Mellen Press.

Volkov, Vadim

2000 “The Concept of Kul'turnost': Notes on the Stalinist Civilizing Process." In Stalinism: New Directions, edited by Sheila Fitzpatrick, 210-30. New York: Routledge.

Whyte, William H.

2000 "New York and Tokyo: A Study in Crowding." In The Essential William H. Whyte, edited by Albert LaFarge, 227-45. New York: Fordham University Press. Originally published in 1977. 